Man and Nature

L'homme et la nature

\title{
Mme Bégon, a Colonial Salon Hostess
}

\section{Catherine Rubinger}

Volume 3, 1984

URI : https://id.erudit.org/iderudit/1011827ar

DOI : https://doi.org/10.7202/1011827ar

Aller au sommaire du numéro

Éditeur(s)

Canadian Society for Eighteenth-Century Studies / Société canadienne d'étude du dix-huitième siècle

ISSN

0824-3298 (imprimé)

1927-8810 (numérique)

Découvrir la revue

Citer cet article

Rubinger, C. (1984). Mme Bégon, a Colonial Salon Hostess. Man and Nature / L'homme et la nature, 3, 89-100. https://doi.org/10.7202/1011827ar

Copyright (C Canadian Society for Eighteenth-Century Studies / Sociéte canadienne d'étude du dix-huitième siècle, 1984
Ce document est protégé par la loi sur le droit d'auteur. L'utilisation des services d'Érudit (y compris la reproduction) est assujettie à sa politique d'utilisation que vous pouvez consulter en ligne.

https://apropos.erudit.org/fr/usagers/politique-dutilisation/ 


\section{Mme Bégon, a Colonial Salon Hostess}

To students of literature and eighteenth century social history the word 'salon' is evocative of those brilliant evenings at Sceaux or in Paris, frequented by the philosophers, artists and writers of a period when France was the centre of the civilised world. Writing of Mme de Lambert, the first of the eighteenth century hostesses in 'ce siècle où les femmes régnèrent par les salons,' Mathurin de Lescure says, 'elle fut une puissance sociale, littéraire, académique, dirigea la mode, régenta le goùt, imposa le ton, fit de son éventail le sceptre de la conversation, donna de ces diners dont le billet d'invitation était le brevet de réputation et d'influence.' ${ }^{\prime}$ Elisabeth Badinter, writing of Mme de Châtelet, says 'Elle aurait aimé réunir autour d'elle et Voltaire, à Cirey, une sorte de petite Académie des sciences. Connaissant l'élite de la pensée scientifique européenne, il n'aurait pas été impossible de réaliser ce rêve.'2

Such were the hostesses and salons that achieved fame, but there were others of lesser stature, which yet conform to the Littre definition of a salon as ' ... La maison où l'on reçoit habituellement compagnie, et particulièrement, bonne compagnie, et où l'on cause. Par extension: la bonne compagnie, les gens du monde. ${ }^{3}$ It might be assumed that a colonial salon, because of its isolation from Paris, would fall into this more general category. But New France had its miniature capitals where women undoubtedly 'reigned.' Of such hostesses, Mme Bégon was a notable example.

Elisabeth Bégon was born in Montreal in 1690 and died in 1755; she was an almost exact contemporary of the two Parisian hostesses, Mme du Deffand and Mme Geoffrin, whose lives most resemble hers. Like them, she wrote letters ${ }^{4}$ which reveal both her personal drama and much 
of the social life of her day. Like theirs, her correspondence is of interest as a portrait of the personalities, manners and values of the age. Yet the geographical and historical characteristics of her milieu are very different from theirs. So, if comparison between the salons of Paris and the salon of Mme Bégon is to be made, certain characteristics of the colonial setting must be sketched.

The first significant difference between the milieu of Paris and that of Mme Bégon is scale. Mme Bégon's world was at once far bigger and far smaller than that of the capital. In terms of population, the urban centres of Montreal, Trois-Rivières and Quebec were very small indeed, but they provided the political and social direction and necessities of life for an immense geographical area, covering much of North America and the West Indies. Whereas the habitués of Paris salons looked intellectually afar and corresponded with England, Germany and Russia, but found Mme Geoffrin's journey to Poland 'une fantaisie des plus excentriques, ${ }^{\prime 5}$ Mme Bégon's acquaintances travelled incessantly. The smallness of her immediate circle and the vastness of the distances surrounding it give to her evocation of New France a curiously kaleidoscopic effect: distance is constantly diminished by people transcending it and bringing news. News from next door and news from abroad, from the distant forts and adjoining colonies, news of friends and news of the enemy form the stuff of Mme Bégon's letters, accounting partially for the fact that her letters, never intended for publication, have become primary sources of Canadian history.

Mme Bégon was writing at a critical period. 'La Nouvelle France est à son déclin. Au milieu des plaisirs des grands et de la misère des petits, elle s'achemine progressivement vers la débâcle de la guerre de Sept Ans.'6 Threatened by war, by famine, by cold and by want, the life-style of New France was one where insecurity, personal and collective, was the human condition. Mme Bégon's life parallelled the hopes and despairs of her time. She was young during the last phase of growth and hope in the thirty years' peace. In her maturity, she knew the corruption, the scandals and the decline of New France. In her old age, she was to see the first stages of conquest, with the loss of Acadia, the twice repeated downfall of Louisbourg. Although she did not live to see the fall of New France she foresaw disaster, her insights being keen and politically acute.

Hers was, indeed, a political milieu. She was born and married into the governing classes of New France. Etienne de Rocbert de la Morandière, her father, was 'gardien du magasin du roy.' Her husband, Claude Michel Bégon, the younger son of a noble family from Blois, came from a line of administrators of New France. He became a Chevalier de St. Louis, thus acquiring the most coveted rank of his world, although his highest post 
was as Governor of Trois Rivières. Her brother-in-law, Michel Bégon, became Intendant of Canada and married the sister of the Minister of Marine, the Conte de Maurepas, second only to the king in authority over New France. Her father-in-law, was Governor of the French West Indies and Intendant de la Généralité de La Rochelle. Her son-in-law, Honoré Michel de Villebois de la Rouvillière, to whom the letters are addressed, was, at the time, in Louisiana, newly promoted from Commissaire Ordonnateur de Montréal, whereas the most powerful man in her circle, the Marquis de la Galissonière, who was her nephew by marriage, was acting Governor of the colony in the absence of the captured La Jonquière.

Not all these connections were helpful to her, however. The Bégons and their powerful relative, Maurepas, considered that Claude Michel Bégon had made a mésalliance, and their marriage occasioned a power struggle between the Governor and the Bishop of Quebec. Such a contretemps was doubtless part of the political education of Elisabeth Bégon who came to pride herself on her discretion and tact, and apparently with reason, since there came to her house everyone of note in New France, including those whom historians admire (La Vérendrye, Hocquart, La Galissonière), those who provoke controversy (Rigauld de Vaudreuil, for example), and those whom history has judged severely, partly because of her judgment (Varin the corrupt, Longueuil the pompous, and Bigot the extravagant).

These are the 'gens du grand monde,' 'les mondains' and 'les personnalités diverses,' the guests of her salon. They are, in the Canadian sense, aristocrats, defined by Chanoine Groulx as 'tout simplement l'homme de classe sociale, noble, seigneur, officier de troupe, de justice, fonctionnaire du gouvernement ou de l'administration, qui se situe au-dessus de la bourgeoisie. ${ }^{7}$ Not thinkers or artists, though some were amateur scientists and well educated, they were preoccupied with practicalities. Their task was to preserve the peace with the Indian allies, to protect trade for France and to hold the colony as a political and religious entity against the growing power of the English, their ambition to make a fortune or at least a solid career with a pension. Few had the vision to transcend the immediate situation and they were not encouraged to do so. Orders and directives came by every mail from Versailles, making it clear that every aspect of life was controlled by the king. Yet there were long periods each winter without mail or news, periods when the land and the climate marked the inhabitants as left to their own resources. This isolation accentuated their strengths and weaknesses, focusing a merciless light on them individually and collectively.

Mme Bégon observes her guests lucidly and, like her Parisian contem- 
poraries, adds her personal touch to her portraits. Since her intention is to amuse her son-in-law, she indulges a taste for light satire, and, because her vision is family-oriented, she presents her acquaintance on a domestic scale. Historical figures appear in unexpected postures as a result. La Vérendrye, home from establishing forts all across the West, is caught flirting in the salons of Montreal where 'C'est la plus jolie chose du monde de voir la mine que La Vérendrye fait à la Martinière. ${ }^{\prime}$ The worldly Bigot is depicted standing with his hands behind his back, apparently bored, while all Montreal dances in his honour. 'S'il danse deux ou trois menuets, c'est tout.' ${ }^{\prime}$ The Baron de Longueuil, whose promotion had been delayed during the life-time of Mme Bégon's husband, is shown 'dans un état triste ... par l'incertitude où il est de savoir s'il sera gouverneur ou non. ${ }^{\prime 10}$ Another day, the Baron arrives drunk at Mme Bégon's house and invites himself to dinner, while M. Varin, the Commissaire Ordonnateur de Montreal, who had succeeded 'le cher fils' in that post, falls down, drunk also, 'sa perruque d'un côté, et lui de l'autre.'11 Priests, bishops, judges, governors and their ladies, are all evoked by her satirical pen, along with the marriages, deaths, gossip and political news. She observes of it all: 'C'est une vraie comédie que le monde. ${ }^{12}$

This society was small. Guy Frégault estimates their number at two hundred and eight, ${ }^{13}$ while Isabel Landels calculates that Mme Bégon mentions three hundred names. ${ }^{14}$ These were the upper classes of urban New France, and of its three towns: Quebec, Trois-Rivières, and Montreal, in all three of which Mme Bégon lived at one time or another. Miniature capitals - ports, garrison towns, centres of law and trade, religion and pleasure - they were, for travellers, a refuge from the hardships of the wilderness, and for their own population a dynamic network of social, political and commercial life. Above all, the towns of New France were parishes and groups of homes. The home, the multipurpose building, was the setting for most human activity, including offduty military life, trade and government. It was in the homes that the majority of public business was conducted and there too that neighbours, colleagues, and visitors were received, fed and entertained. The living rooms, the reception rooms - the salons - were thus at the centre of colonial life.

The domestic setting apparently influenced the style of the receptions. Unlike those of Paris, where 'on fondait un salon au lieu d'aller à l'eglise, on causait au lieu de prier, ${ }^{\prime 15}$ they were rarely deliberately planned. One has the impression from Mme Bégon's letters that the receptions were often spontaneous and improvised according to circumstance: to celebrate the arrival of a traveller, to honour an official, or to entertain 
friends and colleagues after the working day. Louis Franquet has left a description of his welcome by the Governor of Trois-Rivières who succeeded M. Bégon in that post: 'M. le Gouverneur voulut absolument me conduire chez lui: il fallait cèder à ses instances. $Y$ arrivé, je fus présenté à madame son épouse, qui par parenthèse, est une personne des plus accomplies tant par la figure que par l'esprit. Elle est d'ailleurs pleine de grâces et de politesse; ... L'on ne tarda pas ensuite à passer dans la salle à manger. Il y avait une table de vingt couverts servie, je ne dirais pas comme à Paris, d'autant que c'est l'endroit où j'ai vécu le plus frugalement, mais bien avec la profusion et la delicatesse des mets des meilleures provinces de France. On y but toutes sortes de vin, toujours à la glace; jugez du plaisir par le chaud excessif qu'il faisait. Après le dîner, fait une partie de cadrille. ${ }^{\prime} 6$

Franquet's description reveals the sort of entertainment that was offered spontaneously in a home in New France: a good dinner, plenty of wine and a hand at cards to follow. Testimony abounds, and particularly in Mme Bégon's letters, that dancing and gambling were also popular. Claude de Bonnault writes of a prevailing feverish joie de vivre and desire for amusement: 'Comme si l'on n'était pas sûr du lendemain, parce que le risque pour ces hommes était pain quotidien, on se pressait de jouir de tout. On voulait vivre de toutes ses forces, on lisait, on dansait, on jouait aux cartes avec frénésie et l'on aimait. On a beaucoup aimé au Canada en ce temps-là. ${ }^{17}$

Elegant conversation and discussion of the arts also formed part of the entertainment in the Canadian household. Charlevoix found in New France 'un petit monde choisi où il ne manque rien de ce qui peut former une société agréable,' where 'on politique sur le passé, on conjecture sur l'avenir, les sciences et les beaux arts ont leur tour, et la conversation ne tombe point. ${ }^{18}$ Pierre Kalm noted that 'les gens de distinction en général ont bien plus de goût pour l'histoire naturelle et les lettres que dans les colonies anglaises.'19 Frégault states that in the seventeenth century the plays of Corneille and Racine had been performed in New France 'peu après avoir été jouées en France, et on ne manque pas de lectures, ainsi que le démontrent les inventaires de l'époque. ${ }^{20} \mathrm{Mme}$ Bégon confirms the taste for reading that must have formed the subject of some discussion. Her grand-daughter, she writes to le cher fils,' reads all day long, and she lists the books she has bought: 'tous les Corneille de l'univers, les Fables, les Henriade, les Don Quichotte, les Ducerceau' and 'mille dictionnaires latin et français.'21

A certain level of culture thus existed in the society of New France, but estimations of its degree of refinement vary. Contemporary evaluations were on the whole favourable. Les habitants sont affables et de bonne 
société,' wrote Jean Bonnafoux, ${ }^{22}$ and Kalm found the Canadian politeness 'plus raffinée que celle des Hollandais et des Anglais des colonies appartenant à la Grande Bretagne. ${ }^{23}$ Charlevoix found 'des cercles aussi brillants qu'ailleurs, ${ }^{24}$ but Céline Dupré, commenting upon Mme Bégon's letters, remarks that 'ce ne sont pas toujours les plaisirs les plus raffinés que l'on recherche avec tant d'ardeur, en société. A vrai dire, l'aristocratie "montréaliste" semble plutôt rude de moeurs, du moins à en juger par sa façon de festoyer. Ses dîners se transforment souvent en d'interminables gueuletons où l'on "chante sauvage" et boit au point d'avoir peine à danser un menuet. ${ }^{25}$

Refined or less so, and certainly without the distinguished wit of a Voltaire or a Marivaux or - the ultimate accolade of the Parisian salon - an academician, the salons of New France were probably, above all, occasions for the exchange of news and conversation about practical matters. In Mme Bégon's letters, military matters, politics, problems of public morality jostle with intimate jokes, descriptions of the weather and family gossip, leading one to imagine the same mixture of topics in the salons. In these, the strength of outlying forts would have alternated with the ethics of profiteering in flour or the inevitability of liquor smuggling, the illegal trade in furs with the potential of coal mining, the state of the cod fishery with the possibility of growing flax and teaching the 'habitants' to spin. The news of marriages, illnesses and deaths would have been mingled with the need to build mills, to establish a ship building industry, and to replace furs as the staple product of the colony. In the spring all the talk would have been of promotions and the resultant shifts in the rival cliques and power alliances. Then there would be debates about the struggles between church and state, about the right of soldiers to marry, and about the political or commercial role of missionaries in distant forts. There was tension in the military hierarchy and jealousy between the troops of the various settlements, the French despising the colonials and the colonials despising each other in proportion to their distance from authority. The clergy too indulged in endless 'chicanes de précédance' and, if other quarrels were in abeyance, there was the complex rivalry among the Indians to consider and the ever present tension between the governor and his intendant. Each of these topics would have had its partisans, and the arguments about policy and development would have been sprinkled with discussion of the latest measure to prevent fire, the by-laws concerning the construction of houses, or the properties of medicinal herbs. Always the talk would have veered to the shortage of money.

Shortages - of men, of arms, of food, of pay - famine and want, these were the realities behind the brave show and the feverish joie de 
vivre. Mme Bégon's letters reveal poverty at all social levels. She remarks of two households she visits: 'Il y a un air de disette dans ces deux maisons pitoyable. ${ }^{26}$ As a widow without a pension, she has difficulty in making ends meet and much of her correspondence concerns her financial difficulties and comparisons with her former state. Yet Franquet, speaking of the incumbent Governor of Trois-Rivières, says that he had an income of ' 1000 livres au plus. Cela ne suffit point, d'autant que cette ville étant située à moitié chemin de Québec à Montréal, sa maison est le rendez-vous de tous les passagers, et il est si honorable et si généreux qu'il y reçoit le petit comme le grand. ${ }^{27}$

The shortages of food and money, though not unknown to some of the salon hostesses of Paris, were undoubtedly a significant factor in the lifestyle of those of New France, and a determining influence on their role. Most ladies must have known the reality of Mme Du Deffand's 'recette contre l'ennui ... l'exercice du corps, l'application de l'esprit ou l'occupation du cœur. ${ }^{28}$ Most had to do some of the house-work. Mme Bégon refers to herself knitting, cooking, gardening, ${ }^{29}$ doing her own decorating, ${ }^{30}$ supervising the workmen building a new wing to her house, ${ }^{31}$ renting it to Bigot $^{32}$ and - despite her diffidence as a business woman - learning the financial management of a vineyard in France. ${ }^{33}$ In this housewifery, she was not exceptional. At one point she mentions visiting the wives of an ex-Governor and a military commander and finding one of them darning her husband's clothes. ${ }^{34}$

An ability to conjure hospitality and entertainment from an inadequate income obviously belonged to the role of the hostesses in New France. Yet this did not lessen their influence as leaders in the art of gracious living. Franquet's description of his hostess as an accomplished lady is echoed by other visitors. Kalm says 'La Québecoise est une vraie dame française par l'éducation et les manières. ${ }^{35} \mathrm{He}$ remarks that 'les belles dames du Canada ne peuvent entendre aucun barbarisme ni expression inusitée sans rire. ${ }^{\prime 36}$ Charlevoix was gratified by the purity of the language spoken in New France: Nulle part ailleurs on ne parle plus purement notre langue. ${ }^{\prime 37}$ Franquet endorsed this: 'ils parlent un français épuré, n'ont pas le moindre accent, ${ }^{\prime 38}$ and Montcalm observed that les paysans canadiens parlent très bien le français. ${ }^{\prime 39}$ Bougainville mentioned that 'ils parlent avec aisance ... leur accent est aussi bon qu'à Paris. ${ }^{\prime 40}$ That this correctness of speech was the work of the ladies, who taught it along with social conduct, is confirmed by Mme Bégon whose granddaughter recites to $\mathrm{M}$. de La Galissonière 'presque tous les jours quelques fables ou petits vers. ${ }^{\prime 41}$ Superintending the children's education was an important task of the lady of the house. Latin, reading, correct 
behaviour, religious reverence, social tact and poise without haughtiness are the aspects Mme Bégon reports most frequently to the absent father.

Mme Bégon herself, indeed, defines her role in life as that of a mother. It is as such that she signs all her letters, yet, like Mme Geoffrin, she has l'humeur donnante' 42 and so includes in her concerns every one who asks for her help. She puts at their disposal her good connections, her personal qualities of kindness, discretion and common sense, exercising in doing so considerable influence. As she reminds her son-in-law, 'L'estime que ta mère s'est acquise dans le pays lui donne la confiance et l'amitié de personnes qui peuvent beaucoup.' 43 Visited almost daily by the Governor, she is courted by friends and enemies alike in their search for a pension, a promotion, the ear that could lead to favour in Versailles. Receiving courtesy calls, answering requests, arranging introductions, writing references, despatching clothing, comfort and advice are what she calls her 'métier.' On May 1750, she wrote sixty letters before sending a note to her son-in-law. Though often wearied by it all, she can still smile ruefully at the end of a long day: 'J'ai fait des visites tout le jour, dont je suis si lasse que je me donnerais pour deux liards. Quel métier, cher fils, et surtout quand il faut essuyer les compliments de deux communautés. ${ }^{\prime 4}$

It is in her letters concerning her immediate family, however, that we see most clearly her influence on manners and the values that she practised. Her fundamental attitude is one of moderation: in matters of religion, education, work and leisure, she rejects extremes and absolutes, revealing a tendency to be governed by pragmatic courtesy and common sense. She is, for example, devout and regular in church attendance, because she derives consolation from her religion. But she will laugh with her grand-daughter at a dull sermon, and is amused by the hypocritical 'grosses-têtes' bowing to the clergy's thunderous threats of excommunication while all Montreal is dancing in honour of Bigot's visit. ${ }^{45}$ At home she encourages her grand-daughter to read, despite critics who consider that the little girl should learn house-work: 'Je la laisse faire, persuadée que cela lui cultive l'esprit. ${ }^{46}$ Yet in the matter of her grand-daughter's social manners, she is more adamant. She will not tolerate la hauteur' either in her charges or in others. Like Mme du Deffand, she could claim 'ma folie n'est pas la présomption ni la prétention.' ${ }^{\prime 47}$ Like Mme Geoffrin, 'elle dédaignait toute espèce de pose et d'affectation. ${ }^{\prime 48}$ It is one of the comparisons between Canada and provincial France that she makes most often, deploring the French preoccupation with rank and grandeur. She is particularly hurt by the arrogance of her sister's family: 'ce sont des airs de grandeur et de hauteur avec nous qui me font pitié,'49 and 'ils sont tous d'une gloire insupportable. ${ }^{50}$ In a sad letter, she writes of France: 'ce pays n'a d'aimable que le climat. Du reste, il est pire que le Canada pour la 
gloire, l'envie, la jalousie et tout ce qu'il y a de moins bon dans la société. ${ }^{\prime 51}$

Tactlessness and lack of common sense are what she deplores most in her son-in-law when he develops a persecution mania which she does not understand. She scolds him severely for his reckless and haughty behaviour, then, to cure his 'mille chimères dans la tête, ${ }^{\prime 52}$ she offers him advice for success in his career. While acknowledging his scrupulous honesty, she considers it too absolute and urges him to remember his dependents and to make some money. 'Si tu n'as pas l'esprit de gagner quelque chose où tu es, tu mériterais d'être battu, car on ne se fait plus de mystère aujourd'hui de ce métier, et on regarde comme bêtes ceux qui n'ont pas de commerce en tête. Je crains que cela ne t'occupe pas assez.' Lest he find this too severe, she adds, 'Il est vrai qu'il convient en quelque façon beaucoup mieux de s'occuper de son devoir, mais il faut faire en sorte de travailler à l'un et à l'autre. ${ }^{53}$ She reveals a similar sense of bleak reality when she summarises the situation of the colonial civil servant: 'Il faut attendre une place ou être en état de vivre sans le secours du roi. ${ }^{154}$

These qualities of realism and tact together with her social connections and her wit and charm made of Mme Bégon a hostess in the Mme de Lambert, Mme Geoffrin manner. Hospitality was obviously a way of life in New France, and we can deduce that, during her husband's life-time, Mme Bégon's receptions were stylish, lavish and entertaining, with the arts of savoir vivre in the eighteenth century grand manner practised in them. Yet doubt remains as to whether she can be said to have had a salon as literary historians use the word, for the single most significant element of the Parisian salon world was lacking: the deliberate, selfconscious cult of fame and intellectual eminence. Mme Bégon did not entertain to combat ennui nor to ensure personal recognition, nor did she seek to dazzle by her guest list or her theatrical recreations. She did not aspire to celebrity as a femme savante or a friend of the great. Like many another hostess presiding over 'la bonne compagnie, les gens du monde,' she was practising the rites of courtesy and fulfilling the obligations of hospitality at a time and in a society where these were an intrinsic part of civilisation.

That she did so with wit and warmth and that she was surrounded by the men who made the history of eighteenth century New France ensured her a posterity she did not seek and a readership she never intended. Her destiny was to leave a record of her society so clearly marked with the imprint of her personality as to have influenced history's vision of her world. 'Sur cette période troublée de notre histoire,' writes one of her biographers, la correspondance de Mme Bégon ne jette pas tellement une 
lumière nouvelle, susceptible de révéler des faits inconnus ... Ce qu'elle offre de précieux, c'est la découverte du contexte humain. ${ }^{55}$

The human context of her portrait of New France gives it a luminosity quite different from the lustre and artifice that literary historians have attributed to the salons of Paris. It is that of a small society in a vast land, condemned to defeat, but engaged in a valiant task - that of defending an empire and supporting social values. Twin aspects of a single endeavour, both were presided over by a woman whose role as a mother was part of a larger social avocation, that of making life around her as gracious, sensible and kindly as possible.

For that finally was the achievement of the hostesses of New France, as it was of the less intellectual hostesses of Paris - to soften, by common sense and friendship, the harshness of destiny. 'Ne dois-je pas,' asks Mme Bégon, 'toujours chercher autant que je le pourrai à adoucir tout ce que je vois trop amer. ${ }^{56}$ Frégault, summing up his study of New France during the thirty years' peace, in a quotation from Mme Bégon's biographer, de Bonnault, remarks that 'un singulier souci de charité avait humanisé les mœurs.'57 Souci, humaniser, charité - all words that apply to Mme Bégon. These terms might have made her laugh had she known of their application to her, but the thought behind them she would not have found singular, for humanising manners was her métier.

\section{CATHERINE RUBINGER}

Mount St. Vincent University

\section{Notes}

1 Mathurin François Adolphe de Lescure, La Société française au dix-huitième siècle. Les femmes philosophes (Paris: E. Dentu, 1881), p. 9.

2 Elisabeth Badinter, Emilie, Emilie L'Ambition féminine au dix-huitième siècle (Paris: Flammarion, 1983), p. 133.

3 E. Littré, Dictionnaire de la Langue française (Paris: Hachette).

4 Elisabeth Bégon, Lettres au cher fils. Correspondance d'Elisabeth Bégon avec son gendre. 1748-1753 (Montréal: Hurturbise, 1972).

5 Charles de Mouÿ, 'Etude sur Stanislas-Auguste et Mme Geoffrin' in Correspondance du roi Poniatowski et de Madame Geoffrin (Genève: Slatkine Reprints, 1970), p. 52.

6 Céline Dupré, Elisabeth Bégon. Textes choisis, présentés et annotés (Ottawa: Fidès, 1960), p. 10. 
7 Chanoine Lionel Groulx, Histoire du Canada français depuis la découverte (Montréal, 1969), p. 293.

8 Bégon, Lettres, 13 février, 1749, p. 82.

9 Ibid, 14 février, 1749, p. 83.

10 Ibid, 9 juin, 1749, p. 140.

11 Ibid, 29 janvier, 1749, p. 73.

12 Ibid, 21 mars, 1749, p. 104

13 Guy Frégault, La civilisation de la Nouvelle-France 1713-1744 (Ottawa: Fidès, 1969), p. 122.

14 Isabel Landels, 'Correspondance de Mme Bégon,' thèse présentée à la Faculté des Lettres de l'Université Laval, 1947, p. 101.

15 Mathurin de Lescure, 'Madame du Deffand, sa vie, son salon, ses amis, ses lettres,' in Correspondance de la Marquise du Deffand, ed. de Lescure (Genève: Slatkine Reprints, 1971), p. xcix.

16 Louis Franquet, Voyages et Mémoires sur le Canada (Québec: Edition Elysée, 1974), p. 15.

17 Claude de Bonnault, 'La correspondance de Mme Bégon,' in Rapport de l'Archiviste de la Province de Québec (1934-35), 3.

18 P. F-X de Charlevoix, 'Mémoire sur les Colonies Françoises et Angloises de l'Amérique septentrionale' (1739), p. 72.

19 G.W. Marchand (ed.), Voyages de Pierre Kalm dans l'Amérique septentrionale (Mémoires de la Société historique de Montréal, 1880), p. 6.

20 Frégault, La civilisation, p. 216.

21 Bégon, Lettres, début de l'année, 1753, p. 313.

22 J.C. Bonnafoux, Voyage au Canada de 1751 à 1761 (Québec, 1887), p. 35, cited by Frégault, La civilisation, p. 217.

23 Voyages de Pierre Kalm, p. 102.

24 Charlevoix, 'Mémoire,' cited by Frégault, La civilisation, p. 216

25 Dupré, Elisabeth Bégon, p. 15.

26 Bégon, Lettres, 2 juin, 1749, p. 137.

27 Franquet, Voyages, p. 17.

28 Mme du Deffand, letter to Walpole, 17 mai, 1767, in Madame la Marquise de Deffand. Lettres à H. Walpole, Voltaire et quelques autres (Paris: Plasma, 1979), p. 36 .

29 Bégon, Lettres, 17 avril, 1749, p. 114.

30 Ibid, 13 oct., 1750, p. 219.

31 Ibid, 19 avril, 1749, p. 115.

32 Ibid, 19 fev., 1749, p. 86.

33 Ibid, 24 juillet, 1750, p. 197. 
34 Ibid, 2 juin, 1749, p. 137.

35 Voyages de Pierre Kalm, p. 214.

36 Ibid.

37 Frégault, La civilisation, p. 217.

38 Franquet, Voyages, p. 57.

39 Frégault, La civilisation, p. 217.

40 Ibid.

41 Bégon, Lettres, 22 avril, 1749, p. 117.

42 de Mouÿ, Correspondance, p. 41.

43 Bégon, Lettres, 20 fev., 1751, p. 262.

44 Ibid, 2 juin, 1749, p. 137.

45 Ibid, fev., 1749, pp. 71-91.

46 Ibid. début de l'année, 1753, p. 313.

47 Mme du Deffand, to Walpole, 21 mai, 1766, in Madame la Marquise du Deffand, p. 17.

48 de Mouÿ, Correspondance, p. 32.

49 Bégon, Lettres, 20 juin, 1750, p. 192.

50 Ibid, 1 juin, 1750, p. 180.

51 Ibid, 3 mai, 1750, p. 168.

52 Ibid, 3 mai, 1752, p. 292.

53 Ibid, 23 nov., 1750, p. 239.

54 Ibid, 18 août, 1752, p. 301.

55 Dupré, Elisabeth Bégon, p. 11.

56 Bégon, Lettres, 3 mai, 1752, p. 292.

57 de Bonnault, RAPQ, p. 3. 